\title{
Naturalization of Brugmansia suaveolens (Humb. \& Bonpl. ex Willd.) Bercht. \& J.Presl and Gaillardia pulchella Fougeroux in Tripura, India
}

\author{
Panchatapa Bhattacharya, Aparajita Das, Somnath Kar ${ }^{1}$ and B. K. Datta \\ Plant Taxonomy and Biodiversity Laboratory, Department of Botany, Tripura University, Suryamaninagar- \\ 799022, Tripura, India \\ ${ }^{1}$ Communicating author: Department of Botany, Holy Cross College, Lembucherra 799210, Tripura, India \\ E-mail: somnathagt21@gmail.com
}

[Received 07.06.2020; Revised \& accepted 27.06.2020; Published 30.06.2020]

\begin{abstract}
The occurrence of two exotic angiospermic species Brugmansia suaveolens (Humb. \& Bonpl. ex Willd.) Bercht. \& J.Presl and Gaillardia pulchella Fougeroux in in Tripura in naturaliation condition in the state of Tripura in North-east India.
\end{abstract}

Key words: Brugmansia suaveolens and Gaillardia pulchella, Naturalization, Tripura.

\section{INTRODUCTION}

The flora of any region is always changing due to inward and outward migration of different species. At the same time forced introduction of many species by man as crop or ornamental or any type of useful plants is also a continuous process. Many weedy plants also reach to other localities through natural migration or accidentally by human (Das 2002, 2011; McDougall et al. 2011).

Tripura, the second smallest state of North-eastern India is surrounded by Bangladesh in three sides and situated between $22^{\circ} 56^{\prime} \mathrm{N}$ to $24^{\circ} 32^{\prime} \mathrm{N}$ latitudes and between $91^{\circ} 09^{\prime} \mathrm{E}$ to $92^{\circ} 20^{\prime}$ E longitudes (Kar \& Datta 2015). It is positioned at the convergence of Indo-Burman biogeographical zone (Rao 1994) and part of the IUCN recognized Indo-Burma Biodiversity Hotspot (Myers et al. 2000; Mittermeier et al. 2005). The undulating topography, high rainfall and varied altitudes are main factors that have contributed to its rich hilly ecosystemand habitat diversity (Kar et al. 2019).

Deb $(1981,1983)$ studied the flora of Tripura state with later additions. During continuous field survey $(2018$ - 2019), recently two plants were collected from different parts of the state in naturalized condition and were identified as Brugmansia suaveolens (Humb. \& Bonpl. ex Willd.) Bercht. \& J.Presl and Gaillardia pulchella Fougeroux.

Brugmansia suaveolens (Solanaceae) is a native of South-Eastern Brazil and is referred as Brazil's white angel trumpet angel's tears and snowy angel's trumpet. The species was thought to be extinct in the wild. Like several other species of Brugmansia, it exists in areas outside its native range. It is a tender shrub or small tree with large semi-evergreen leaves and fragrant yellow, pink or white trumpet-shaped large corolla. The geographical locations of the species from where it was collected from Jampui (N 24 $4^{\circ} 00^{\prime} 22.79^{\prime \prime}$ and E 092 $\left.16^{\prime} 48.85^{\prime \prime}\right)$ and of

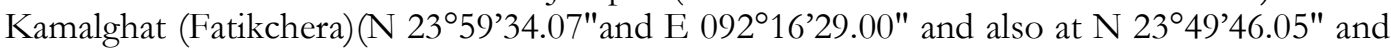
E $091^{\circ} 22^{\prime} 33.88^{\prime \prime}$ E) of Tripura, India.

On the other hand, Gaillardia pulchella (Asteraceae) grow best in open, well-drained soils and full direct sunlight, is native to Central \& S. U.S.A. to N. Mexico (POWO 2020). They are 
favourites as cut flowers and propagated by seeds (Bailey 1976). Blanket flower (Gaillardia sp.) or firewheel or Indian blanket is extensively cultivated in many areas for flower production. It is one of the hardiest annual can be grown in a wide range of tropical to temperate climate. This is substitute flower crop for Chrysanthemum spp. and China-aster (Bose et al. 2003). There are about 28 accepted species and none of them is native to Indian subcontinent. However, here in Tripura, the was found in naturalized state in the Suryamaninagar $\left(\mathrm{N} 23^{\circ} 45^{\prime} 50.4^{\prime \prime}\right.$ and $\mathrm{E}$ 091¹5’38.2" ).

So, the present paper reports the naturalization of two exotic species in the North-east Indian state of Tripura along with their description and photographs. The voucher specimens has been deposited in the Tripura University Herbarium.

\section{TAXONOMIC TREATMENT}

Brugmansia suaveolens (Humb. \& Bonpl. ex Willd.) Bercht. \& J.Presl, Prir. Rostlin. 1(Solanac.): 45. 1823; Zhang et al., Fl. China 17: 300. 1996. [Solanaceae] [Figures 1 \& 2 ]

Vernacular name: Angel's Trumpet.

Erect, much-brached shrubs, $150-250 \mathrm{~cm}$ tall, stem soft-wooded. Stems solid, terete, green when young, grayish on maturity. Leaves simple, alternate; Lamina lanceolate, $17.4-22.7 \times 7.1$ - $10.4 \mathrm{~cm}$, entire, acute, base attenuate, veins reticulate with prominent mid-vein, herbaceous, sticky-hairy; petioles $3-4 \mathrm{~cm}$ long, terete, hairy. Flowers commonly solitary and axillary, pendulous, hypogynous; pedicel $2-2.5 \mathrm{~cm}$ long; calyx $10-10.5 \mathrm{~cm}$ long, 5-lobed, united up to the middle, lobes subulate, acute, green, deciduous; corolla trumpet-shaped (campanulate), $25-30 \mathrm{~cm}$ long, 5-lobed, contortate-folded, generally white, pale pink of yellow in some

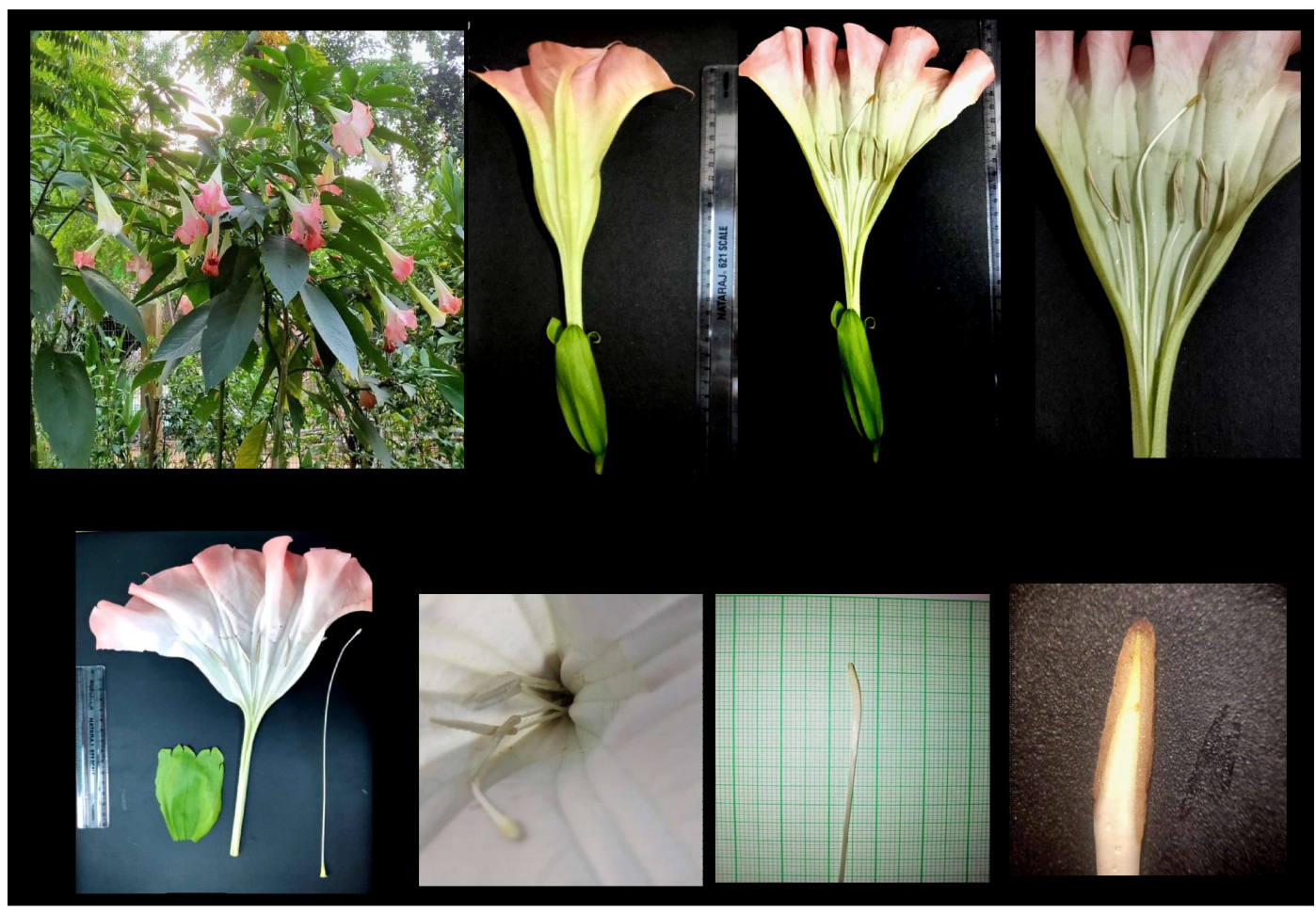

Figure 1. Brugmansia suaveolens (pink-flowered): A. Whole plant; $\mathbf{B}$ to $\mathbf{D}$. Flower, calyx, corolla, androecium, gynoecium; F to $\mathbf{H}$. Stigma 
cultivars; stamens 5, epipetalous, anthers basifixed, bilocular, $2.5-3 \mathrm{~cm}$ long. Carpels 2; ovary rounded-oblong, conical above, glabrous, placentation- axile; style simple, $20-22 \mathrm{~cm}$ long; stigma oblong with rounded tip. Fruits terete-oblong, conical upwards, smooth, green; seeds numerous.

Habitat: In its introduced range, Brugmansia suaveolens occupies lowland rainforest, forest edges, disturbed habitats, riverbanks and urban open spaces.

Flowering: October - February in Tripura.

Specimen cited: Tripura, Tripura University, Bhattacharya et al., TUH-3901, Dated 09.10.2019.

Distribution: Native of Brazil but introduced widely in subtropical to temperate areas of the world and has naturalized in many areas.

Indian distribution: Maharashtra, Karnataka, Andhra Pradesh, West Bengal, Assam, Tripura.

State distribution: Throughout the state of Tripura; naturalized.

Use: Brugmantia suaveolens is a popular garden plant. It is grown for its pendulous large-showy and attractive blooms. It can be smoked, eaten, drunk as a tea, or taken as an enema. In Tanzania it is added to beer. Traditional healers use its dried leaves with tobacco to induce diagnostic visions for treating various diseases. It is occasionally used as a live hedge in Uganda. Extracts of flowers have shown pain-killing (antinociceptive) activity in mice. There is a wide range of medicinal and spiritual uses, many shared with other species and hybrids, among the indigenous people who cultivate it (Hay et al. 2012).

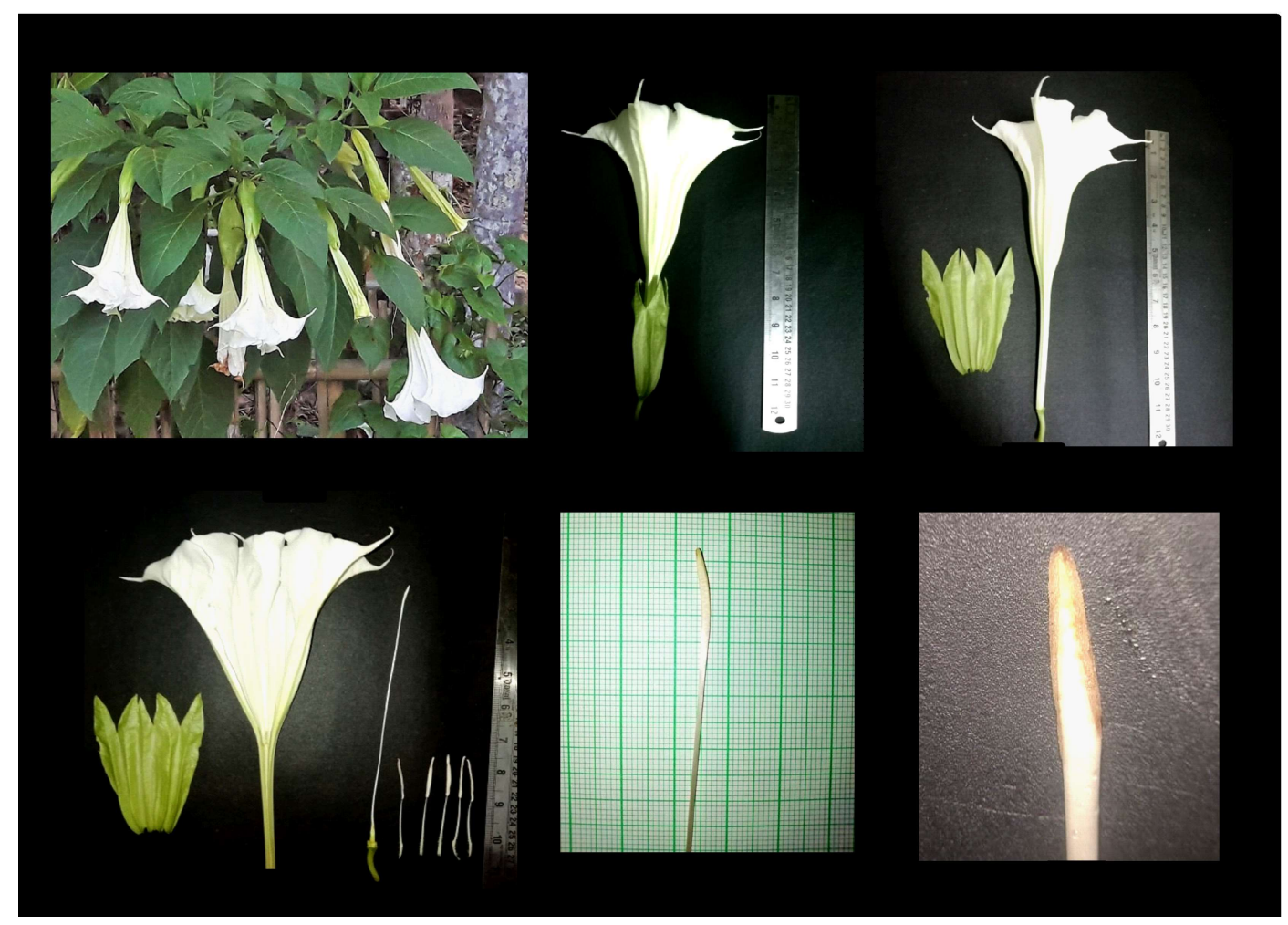

Figure 2. Brugmansia suaveolens (White-flowered): I. Whole plant; J to L. Flower, calyx, corolla, androecium, gynoecium; $\mathbf{M}$ to N. Stigma 


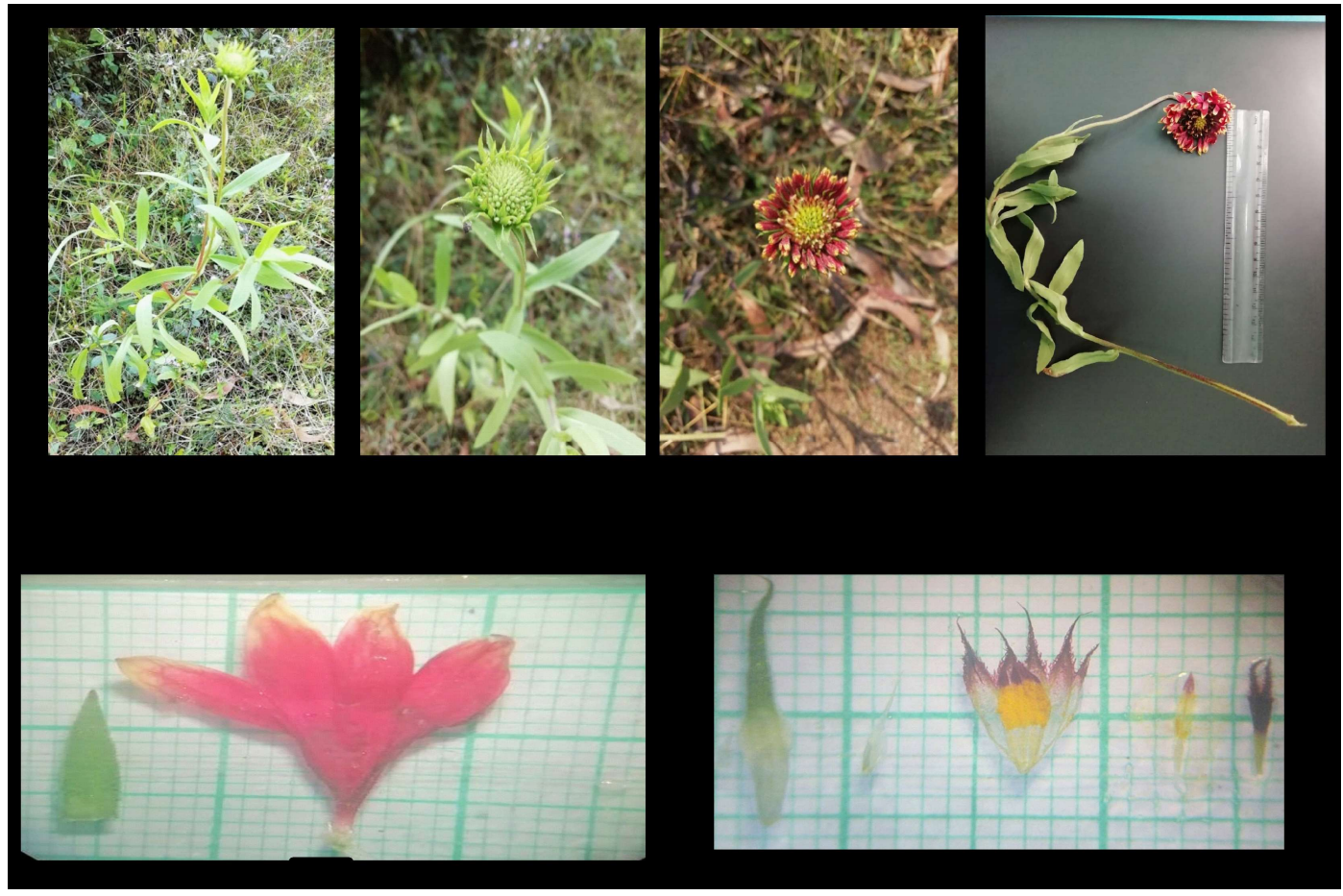

Figure 3. Gaillardia pulchella: A - C. Whole plant; D. A flowering twig; E splitted ray floret; F. splitted disc-floret

Gaillardia pulchella Fougeroux, Hist. Acad. Roy. Sci. Mém. Math. Phys. (Paris, 4to). 1786: 5, fig. 1. 1788. [Astaraceae] [Figure 3]

Vernacular name: Blanket flower, Firewheel, Girasol Rojo.

Annual herb, lower branches prostrate, spreading, flowering branches erect, spreading over 20 $-60 \mathrm{~cm}$. Stems rigid-herbaceous, profusely branched, solid, terete, hairy, green. Leaves simple, alternate, cauline, sessile to subsessile, exstipulate; lamina linear, oblong, $5-10 \mathrm{~cm} \times 4-12$ $\mathrm{mm}$, herbaceous. Capitulum with ray and disc florests; pappus reduced to scales; ray florets usually $20-28$; corolla ligulate, 4-lobed, usually reddish to purplish proximally, yellow to orange distally, $12-20 \mathrm{~mm}$ long; disk-florets numerous; corolla tubular, 5-lobed; yellowish to brown, often bicoloured; throat campanulate, $6-9 \mathrm{~mm}$; lobes deltate, often attenuate hairy; stamens 5, epipetalous, filaments white, glabrous, $1.5-2.5 \mathrm{~mm}$ long; anthers bilobed, syngenesious, purplish yellow, basifixed. Carpels 2, inferior, 1- chambered with one ascending anatropus ovule on basal placentation; style simple, $1.3-2.2 \mathrm{~mm}$; stigma feathery or bifid.

Habitat: Sunny and sandy, fast-draining and soils. They rarely survive the winter in heavier soil.

Flowering: May to August.

Specimens cited: Tripura, Tripura University campus, Bhattacharya et al., TUH-3912, dated 09.10.2019.

Distribution: Native to Eastern and south-central United States, Mexico, Florida, Arizona. Widely introduced as ornamental herb to tropical to subtropical areas.

Indian distribution: Maharashtra, Karnataka, Andhra Pradesh, West Bengal, Tamil Nadu, Jammu and Kashmir, Sikkim, Rajasthan, Uttar Pradesh, Delhi, Haryana and Kerala. 
State distribution: Suryamaninagar, West Tripura; naturalized.

Use: Mass plantings for beds and borders, rock gardens, naturalize in meadows, cottage gardens or native wildflower gardens (www.missouribotanicalgarden.org). Tea of root for gastroenteritis, chewed powdered root applied to skin disorders and for sore eyes (wildflower.org/plants,2020).

\section{Acknowledgements}

Authors are thankful to Tripura University for providing research facilities.

\section{LITERATURE CITED}

Bailey, L.H. 1976. Hortus Third. Macmillan Publishing Co., Inc., Third Avenue, New York.

Bose, T.K.; Yadav, L.P.; Pal, P.; Das, P. \& Parthasarthy, V. 2003. Commercial flowers. Vol. 2. $2^{\text {nd }}$ Edn., Naya Udyog, Kolkata.

Das, A.P. 2002. Survey of naturalised exotics in the flora of Darjiling Hills, West Bengal, (India). J. Econ. Tax. Bot. 26(1): 31 - 37.

Das, A.P. 2011. Conservation efforts for East Himalayan Biodiversity and need for the establishment of corridors. In: C. Ghosh \& A.P. Das, Recent Studies in Biodiversity and Traditional Knowledge in India. Sarat Book House, Kolkata. Pp. 329 - 346.

Deb, D.B. 1981 \& 1983. The flora of Tripura state. Volumes 1 and 2. Today and Tomorrow's Printers and Publishers, New Delhi.

Hay, A.; Gottschalk, M. \& Holguín, A. 2012. Huanduj - Brugmansia. Florilegium, Sydney \& Royal Botanic Gardens, Kew.

Kar, S. \& Datta, B.K. 2015. A glimpse of the traditional uses of plants by Koloi subtribe of Tripura. J. Bot. Soc. Beng. 69(2): 147 - 152.

Kar, S.; Das, A.; Das, D. \& Datta, B. K. 2019. New distributional records of Cleome rutidosperma DC. and Ruellia simplex C.Wright for Tripura, India. Pleione 13(2): 425 - 429.

McDougall, K.L.; Khuroo, A.A.; Loope, L.L.; Parks, C.G.; Pauchard, A.; Reshi, Z.A.; Rushworth, I. \& Kueffer, C. 2011. Plant Invasions in Mountains: Global Lessons for Better Management. Mount. Res. Develop. 31(4): 380 - 387.

Mittermeier, R.A.; Gil, P.R.; Hoffmann, M.; Pilgrim, J.; Brooks, T.; Mittermeier, C.G.; Lamoreux, J.; Da Fonseca, G.A.B. 2005. Hotspots Revisited: Earth's Biologically Richest and Most Endangered Terrestrial Ecoregions. Conservation International.

Myers, N.; Mittermeier, R. A.; Mittermeier, C. G.; da Fonseca, G. A. B. \& Kent, J. 2000. Biodiversity hotspots for conservation priorities. Nature 403: 853 - 858.

Rao, R.R. 1994.Biodiversity in India: Floristic Aspects. Bishen Singh Maendra Pal Singh, DehraDun. www.plantsoftheworldonline.org 